\title{
Rozwój głowic piezoelektrycznych do pomiarów dwójłomności akustycznej
}

\author{
Development of piezoelectric probeheads \\ for acoustic birefringence measurements
}

\section{Streszczenie}

W artykule opisano rozwój głowic ultradźwiękowych do pomiarów dwójłomności akustycznej, budowanych od początku lat 70. ub.w. w Pracowni Badań Ultradźwiękowych prof. Juliana Deputata, a obecnie w Pracowni Badań Nieniszczących Zakładu Wytrzymałości Materiałów IPPT PAN. W pracy omówiono różne zastosowania pomiarów dwójłomności akustycznej, a także przedstawiono historię rozwoju głowic wyposażonych w przetworniki piezoelektryczne. Opisane głowice budowane były głównie z myślą o pomiarach naprężeń własnych $\mathrm{w}$ wieńcach monoblokowych kół kolejowych. Przedstawiono różne układy przetworników, w jakie wyposażano kolejno głowice, oraz zalety i wady zbudowanych głowic.

\section{Wstęp}

W latach 50. ub.w., w czasie badania ultradźwiękowego monokryształów zauważono, że ultradźwiękowa fala poprzeczna rozchodząca się w anizotropowym materiale ulega w pewnych przypadkach rozłożeniu na dwie fale składowe o wzajemnie prostopadłych kierunkach polaryzacji, rozchodzące się z różnymi prędkościami. Przez analogię do zjawiska rozdwojenia promienia świetlnego zwanego dwójłomnością optyczną, zjawisko zmiany polaryzacji fal ultradźwiękowych zostało nazwane dwójłomnością akustyczną (ang. acoustic birefringence). Niebawem stwierdzono, że podobne zjawisko zachodzi również w materiałach izotropowych, jeśli wywołane zostaną w nich naprężenia. Okazało się, że naprężenie jest źródłem anizotropii, co poddało myśl, że badania dwójłomności akustycznej, podobnie jak badania elastooptyczne, mogą być wykorzystane do oceny naprężeń i ich rozkładów. Opis zjawiska dwójłomności akustycznej wywołanej

Dr hab. inż. Jacek Szelążek, prof. nadzw. - IPPT PAN Warszawa.

\section{Abstract}

The paper describes the development of ultrasonic probeheads, built since 70-ties in Ultrasonic Testing Division lead by prof. Julian Deputat and than in Nondestructive Testing Division IPPT PAN. Presented are applications of acoustic birefringence measurements and the history of development of probeheads equipped with piezoelectric transducers. Described are probeheads with various piezoelements configurations, designed mainly for residua stress evaluation in monoblock railroad wheels. Presented are advantages and disadvantages of various probeheads. w metalu działaniem sił zewnętrznych [1], przedstawiony w 1959 r., uchodzi za pierwszą pracę o wykorzystaniu fal ultradźwiękowych do oceny naprężeń.

Początkowo wielu badaczy, chcąc wyznaczyć różnice prędkości fal poprzecznych powstałych w wyniku rozłożenia fali poprzecznej na dwie fale o wzajemnie prostopadłych kierunkach polaryzacji i rozchodzących się z różnymi prędkościami, stosowało podobne podejścia jak w badaniach elastooptycznych [2]. Mierzona była amplituda fal poprzecznych, spolaryzowanych pod kątem $45^{\circ}$ względem kierunku naprężenia. Amplituda była proporcjonalna do przesunięcia fazowego fal powstałych w wyniku rozłożenia nadanej fali na dwie składowe o wzajemnie prostopadłych kierunkach polaryzacji. Z przesunięcia fazowego, proporcjonalnego do różnicy prędkości propagacji fal składowych, ocenianego na podstawie spadku amplitudy impulsu, obliczano wartość naprężenia. Metoda ta okazała się jednak mało dokładna i mało praktyczna. Lepszym sposobem oceny dwójłomności akustycznej okazały się pomiary czasu przejścia fal poprzecznych. Ten sposób znalazł szerokie zastosowanie dzięki rozwojowi aparatury do precyzyjnych pomiarów czasu przejścia (np. technika sing-around). 
Dwójłomność akustyczną B oblicza się z zależności:

$$
B=B_{T}+B_{N}=2 \frac{V_{2}-V_{1}}{V_{2}+V_{1}}=2 \frac{t_{1}-t_{2}}{t_{1}+t_{2}}=B_{T}+\left(\sigma_{1}-\sigma_{2}\right) \cdot\left(\beta_{123}-\beta_{122}\right)
$$

gdzie: $B_{T}$ - dwójłomność wywołana teksturą, wyznaczana doświadczalnie; $B_{N}-$ dwójłomność wywołana naprężeniami $\sigma_{1}, \sigma_{2} ; V_{1}, V_{2}$ - prędkości fal o polaryzacji w kierunkach 1 i $2 ; t_{1}, t_{2}$ - czasy przejścia fal o polaryzacji w kierunkach 1 i $2 ; \beta_{1}, \beta_{2}$ - współczynniki elastoakustycznej.

Zaletą techniki opartej na pomiarze dwójłomności jest to, że dostarcza ona informacji uśrednionej na drodze fal poprzecznych, a więc $z$ całej grubości materiału. Do pomiaru nie jest konieczna dokładna znajomość grubości elementu. Drugą zaletą jest to, że wynik jest praktycznie niezależny od temperatury obiektu. Te cechy spowodowały, że pomiary dwójłomności znalazły wiele zastosowań. Pierwsze z nich to pomiary naprężeń obwodowych w wieńcach monoblokowych kół kolejowych [3]. We Francji badania dwójłomności są wykorzystywane do oceny stanu naprężeń własnych w odkuwkach ze stopów lekkich [4]. Technika ta może być również wykorzystywana do oceny stopnia degradacji pełzaniowej stali energetycznych [5].

Należy pamiętać, że różnice prędkości fal poprzecznych o wzajemnie prostopadłych kierunkach polaryzacji, będące wynikiem naprężeń lub tekstury materiału, są niewielkie. Przykładowo naprężenie rozciągające w wieńcu koła kolejowego o wartości $100 \mathrm{MPa}$ jest źródłem dwółłomności $B_{N}$ równej jedynie 0,079\%. Ocena stanu materiału tą techniką wymaga więc dokładnych pomiarów czasów przejścia fal poprzecznych.

Duże kłopoty sprawiała w latach 60 . generacja i detekcja fal poprzecznych wprowadzonych prostopadle do powierzchni. Problemy te wynikały głównie z braku sposobów przenoszenia drgań ścinania i trudności z operowaniem delikatnymi i stosunkowo mało skutecznymi stosowanymi wówczas przetwornikami kwarcowymi. Początkowo przetworniki przyklejano na stałe do powierzchni próbki [6], później przyciskano je, stosując siłowniki hydrauliczne, jeszcze później opracowywano specjalne środki zdolne do przenoszenia naprężeń ścinających, takie jak: salicylany fenylu [7] czy roztwór boraksu w glicerynie.

Obecnie głowice normalne na fale $\mathrm{SH}$ i specjalne ośrodki sprzęgające znajdują się w katalogach większości producentów sprzętu do badań ultradźwiękowych. Są to głowice kontaktowe, w których przetwornik piezoelektryczny chroniony jest jedynie cienką warstwą ochronną, lub przetworniki z liniami opóźniającymi wykonanymi z topionego kwarcu (materiału o niskim współczynniku tłumienia fal poprzecznych). W odróżnieniu od głowic normalnych na fale podłużne, w których linie opóźniające są wymienne, w głowicach na fale $\mathrm{SH}$ linie te są na stałe połączone (sklejone) z przetwornikami.

Teoretycznie do pomiaru dwójłomności akustycznej wystarczy jedna głowica na fale poprzeczne i odpowiedni ośrodek sprzęgający. Ocena stanu materiału czy naprężeń na podstawie zmierzonej dwójłomności akustycznej wymaga jednak precyzyjnych pomiarów czasów przejścia fal o różnych kierunkach polaryzacji. Obracanie standardowej głowicy, konieczne do zmiany kierunku polaryzacji fal, pociąga za sobą niezamierzoną zmianę grubości warstwy sprzęgającej. W pracy opisano rozwój głowic ultradźwiękowych do pomiarów dwójłomności, głównie w wieńcach kół kolejowych, budowanych od początku lat 70. ub.w. w Pracowni Badań Ultradźwiękowych prof. Juliana Deputata, a obecnie w Pracowni Badań Nieniszczących IPPT PAN.

\section{Głowice do pomiarów dwójłomności akustycznej}

\section{Nadawanie i odbiór fal poprzecznych rozchodzą- cych się prostopadle do powierzchni}

Do nadawania i odbioru fal SH stosowane są obecnie przetworniki z ceramiki piezoelektrycznej spolaryzowanej na drgania ścinania. Są to przetworniki wykonane $z$ takich samych tworzyw jak przetworniki na drgania grubościowe (stosowane w głowicach normalnych na fale podłużne). Jedyną różnicą jest to, że kierunek polaryzacji jest styczny, a nie prostopadły do powierzchni przetwornika. Oznacza to, że blok ceramiki musi być spolaryzowany przed pocięciem go na płytki. Ogranicza to maksymalny wymiar przetworników, równy grubości bloku w czasie polaryzacji, przeważnie do $12 \mathrm{~mm}$. Inna różnica to prawie o połowę mniejsza grubość przetwornika na drgania ścinania w porównaniu z przetwornikiem na drgania grubościowe o tej samej częstotliwości. Dopasowanie akustyczne przetwornika do badanego materiału można uzyskać stosując pomiędzy nimi warstwę ćwierćfalową wykonaną z mieszaniny żywicy epoksydowej i proszku wolframowego lub korundowego. Pod względem dopasowania akustycznego grubość warstwy powinna być nieparzystą wielokrotnością $1 / 4$ długości fali $w$ warstwie. Dla częstotliwości fali równej 2 i $4 \mathrm{MHz}, 1 / 4$ długości fali w materiale warstwy wynosi jedynie ok. 0,15 i $0,08 \mathrm{~mm}$. Jest to grubość zbyt mała, aby warstwa skutecznie spełniała funkcję ochronną. Aby uzyskać możliwie wysoką odporność warstwy ochronnej na uszkodzenia mechaniczne, w opisanych dalej głowicach warstwa ochronna wykonana z mieszaniny żywicy epoksydowej i korundu była grubsza od $1 / 4$ długości fali. Korundowy wypełniacz zwiększa odporność warstwy na ścieranie i jednocześnie, dzięki dużej prędkości propagacji fali w korundzie, akustyczną oporność falową warstwy.

W latach 70. wykonano badania wpływu grubości warstwy ochronnej na amplitudę i kształt impulsów fal poprzecznych w badaniach techniką echa. Celem pomiarów było znalezienie grubości warstwy zapewniającej z jednej strony skuteczną ochronę przetwornika, a z drugiej wystarczającą w pomiarach amplitudę impulsu. Badania prowadzono pobudzając przetwornik 
o częstotliwości rezonansowej $2 \mathrm{MHz}$, wykonany z ceramiki PP9 (CERAD), impulsem o czasie narastania 15 ns. Pomiary wykonano, na stalowej próbce o gładkiej powierzchni, a grubość warstwy ochronnej zmniejszano, szlifując czoło głowicy pomiędzy kolejnymi pomiarami. Uzyskano maksima amplitudy (echo dna próbki o grubości $35 \mathrm{~mm}$ ) dla warstw o grubościach 0,7 i $1,1 \mathrm{~mm}$. Odpowiadają one w przybliżeniu pięcio- i siedmiokrotnej grubości warstwy ćwierćfalowej. Widoczne było też minimum amplitudy dla grubości warstwy nieco większej od $0,5 \mathrm{~mm}$ i ciągły spadek amplitudy dla grubości większych niż 1,1 mm. Przeprowadzone doświadczenie pozwoliło na zastosowanie w budowanych głowicach o częstotliwości $2 \mathrm{MHz}$, bez uszczerbku dla amplitudy sygnału i jego przebiegu czasowego, stosunkowo grubej i odpornej na uszkodzenia warstwy o grubości $1,1 \mathrm{~mm}$.

\section{Głowica jednoprzetwornikowa, obracana}

Pierwsze głowice, o częstotliwościach 2 i $4 \mathrm{MHz}$ i przetwornikach o bokach od 6 do $12 \mathrm{~mm}$, wykonywane były jako głowice obracane. Aby zapewnić, że pomiary dla dwóch polaryzacji będą wykonywane dokładnie w tym samym miejscu, głowice osadzone były w uchwytach mocowanych magnesami do badanego elementu. Uchwyty te, wykonane ze sprężystej blachy, miały również dociskać głowice do powierzchni elementu i tym samym minimalizować grubość warstwy sprzęgającej. Doświadczenia z takimi głowicami pokazały, że zmiany sprzężenia wywoływane obrotem głowicy są powodem rozrzutu wyników pomiarów. Dodatkowo konieczność obracania głowicy spowalniała pomiary.

\section{Głowica sześcioprzetwornikowa}

W celu wyeliminowania niedoskonałości obracanych głowic w 1978 r. powstała głowica 6-przetwornikowa, przeznaczona do badania wieńców kół kolejowych. Schemat jej budowy pokazano na rysunku 1. Głowica ta zawierała dwa prostokątne przetworniki nadawcze o wzajemnie prostopadłych kierunkach polaryzacji i cztery wąskie przetworniki odbiorcze połączone parami równolegle. Kierunki polaryzacji przetworników zaznaczono na rysunku strzałkami. Podwojenie i usytuowanie przetworników odbiorczych po bokach przetworników nadawczych, a więc w pewnej odległości od siebie, miało spowodować uśrednianie wpływu lokalnych zmian grubości warstwy sprzęgającej na mierzone czasy przejścia, a wydłużony kształt zespołu przetworników dobrze wpisywał się w obrys wąskiej powierzchni czoła wieńca koła kolejowego. W stalowe blachy tworzące boki głowicy wmontowano magnesy stałe przyciągające głowicę do powierzchni koła. Głowica ta współpracowała z aparatem DEBRO-20 i wykorzystana została w pomiarach naprężeń własnych w wieńcach kół monoblokowych wykonanych w Vitry dla Europejskiej Unii Kolejowej [8].

Badane koła były starannie obrobione mechanicznie i wykonane ze stali pochodzącej z odlewania ciągłego, charakteryzującej się wysoką czystością i jednorodnością akustyczną. Nieistotny więc był fakt, że obszary materiału obejmowane przez wiązki fal poprzecznych o różnych kierunkach polaryzacji nie pokrywały się i były rozsunięte w kierunku obwodowym wieńca. Natomiast rozdzielenie obszarów penetracji fal o różnych kierunkach polaryzacji okazało się wadą tej głowicy w czasie pomiarów na elementach wykazujących anizotropię strukturalną (np. odlewanych, staliwnych kołach kolejowych). Inną wadą tej głowicy, widoczną szczególnie w czasie pomiarów prowadzonych na elementach o chropowatych powierzchniach, okazały się błędy wynikające z różnic grubości warstw łączących pod sześcioma rozsuniętymi przetwornikami. Okazało się, że powtarzalne wyniki pomiarów dwójłomności uzyskuje się, przyjmując średnią arytmetyczną z dwóch pomiarów wykonanych w tym samym miejscu, dla dwóch położeń głowicy różniących się o $180^{\circ}$. Tak więc, pomimo zastosowania wielu przetworników, nadal najlepszym sposobem pomiaru okazało się obracanie głowicy. Jeszcze jedną praktyczną niedogodnością tego rozwiązania była stosunkowo duża powierzchnia styku głowicy z powierzchnią elementu, co utrudniało szybkie „wyciśnięcie” nadmiaru gęstego środka łączącego spod głowicy.

\section{Głowica pięcioprzetwornikowa}

Próbą wyeliminowania wad opisanych wyżej głowic, a głównie konieczności obrotu, była zbudowana w 1992 r. głowica 5-przetwornikowa, składająca się z jednego przetwornika nadawczego i kilku małych przetworników odbiorczych [9].

Jej cechą charakterystyczną jest to, że przetwornik nadawczy generuje falę poprzeczną spolaryzowaną pod kątem $45^{\circ}$ względem kierunków osi akustycznych materiału. Anizotropia materiału powoduje rozłożenie wytworzonej fali na dwie czyste fale poprzeczne rozchodzące się z różnymi prędkościami, spolaryzowane zgodnie z kierunkami osi akustycznych materiału.

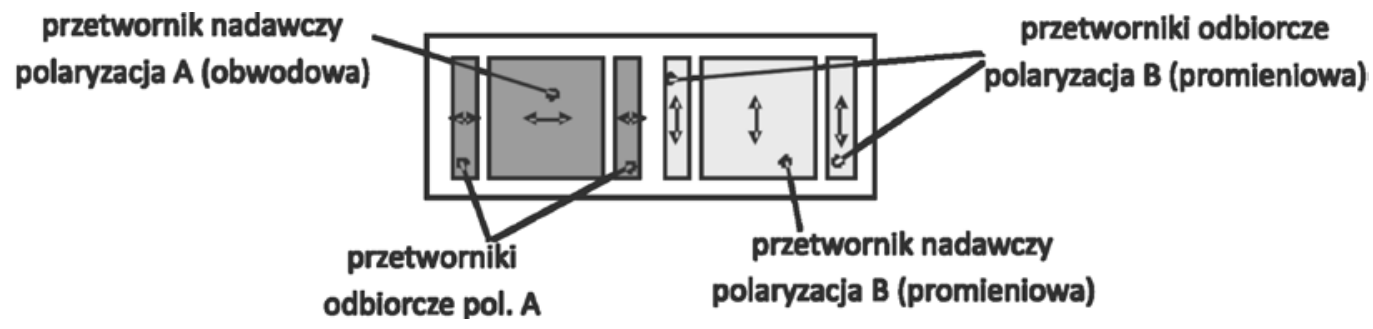

Rys. 1. Układ przetworników (widok z góry) sześcioprzetwronikowej głowicy do pomiaru dwójłomności akustycznej w wieńcach kół monoblokowych Fig. 1. Transducer array (top) of six-transducer head to measure the acoustic birefringence monoblock wheel rims 


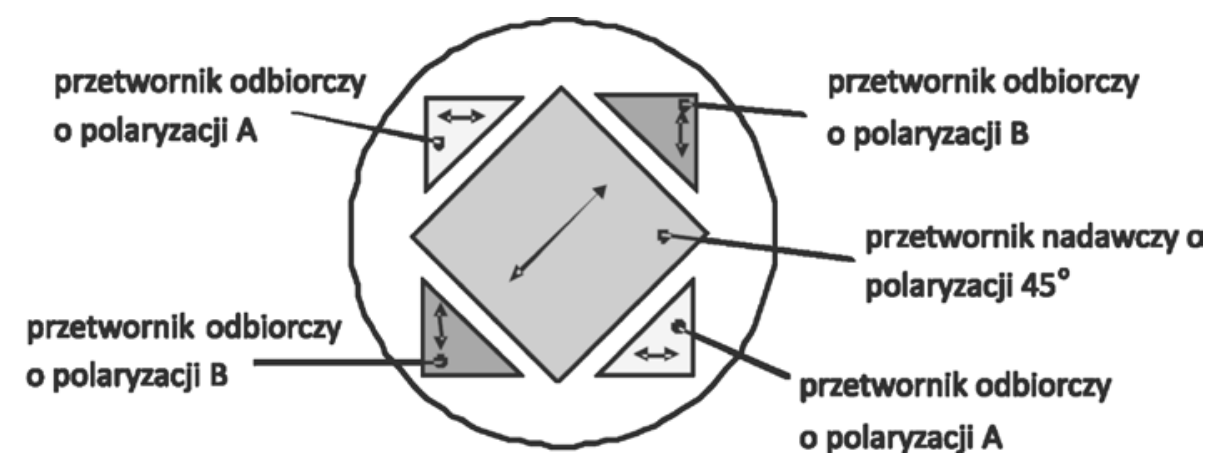

Rys. 2. Układ przetworników w nieobracanej, pięcioprzetwornikowej głowicy do pomiaru dwójłomności akustycznej Fig. 2. The system of transmitters is not rotating of five- transducers head for measuring acoustic birefringence

Małe przetworniki odbiorcze, ustawione wokół przetwornika nadawczego, mają parami polaryzacje zgodne z kierunkami osi akustycznych. Dzięki temu każdy $z$ nich reaguje jedynie na dochodzącą do niego falę o zgodnym kierunku polaryzacji. Zaletą rozwiązania jest możliwość pomiaru dwójłomności bez konieczności obracania głowicy w czasie pomiaru oraz penetracja w przybliżeniu tego samego obszaru materiału falami o różnych kierunkach polaryzacji. Układ przetworników w głowicy pokazano na rysunku 2.

Badania przeprowadzone na stalowych próbkach wykazały, że wyniki uzyskane tą głowicą są porównywalne $z$ wynikami otrzymywanymi głowicą obracaną, z pojedynczym przetwornikiem nadawczo-odbiorczym. Głowica taka była $z$ powodzeniem zastosowana w pomiarach naprężeń w wieńcach staliwnych kół odlewanych [10]. Jej zaletą okazało się wyraźne skrócenie czasu pomiaru (brak konieczności obracania głowicy). Wadą natomiast szczególnie w przypadku kół odlewanych, charakteryzujących się wąską płaską powierzchnią po zewnętrznej stronie wieńca, była znaczna średnica głowicy. Przy zastosowaniu przetwornika nadawczego o boku $12 \mathrm{~mm}$ średnica tulei obejmującej wszystkie 5 przetworników przekraczała $28 \mathrm{~mm}$.

\section{Głowica trójprzetwornikowa}

Wynikiem prac nad zmniejszeniem średnicy głowicy była głowica trójprzetwornikowa. Dodatkowym powodem pracy nad tą głowicą była chęć zmniejszenia liczby przetworników (do każdego z nich trzeba przylutować dwa przewody, a stosowane wówczas przetworniki prod. CERAD miały elektrody napylane cienką i trudno lutowaną warstwą srebra). Nowa głowica pra- cowała na tej samej zasadzie co głowica pięcioprzetwornikowa z tym, że zamiast czterech przetworników odbiorczych ustawionych na zewnątrz, zastosowano dwa przetworniki odbiorcze ustawione w otworze wyciętym w przetworniku nadawczym. Schemat ułożenia przetworników pokazano na rysunku 3. Przetworniki odbiorcze pochodziły z kółka wyciętego z przetwornika nadawczego. Głowica ta wykazała swą przydatność w pomiarach naprężeń w kołach kolejowych i weszła na wyposażenie mierników DEBBIE. Zewnętrzna średnica stalowej tulei chroniącej zestaw przetworników została zmniejszona do akceptowalnych $22 \mathrm{~mm}$.

Doświadczenia zdobyte w czasie prac nad głowicami i ich użytkowaniem wykazały, że głowice wieloprzetwornikowe wymagają korygowania wyników pomiaru dwójłomności o poprawkę, indywidualną dla każdej głowicy. Wynika to z tego, że przetworniki głowicy, wskutek błędów wykonawczych, nie leżą idealnie w jednej płaszczyźnie. Jeśli w głowicy pokazanej na rysunku 5 jeden z przetworników odbiorczych leży nieco wyżej (dalej od powierzchni materiału) niż drugi przetwornik odbiorczy, to czas przejścia fali do tego przetwornika jest dłuższy. Przykładowo, jeśli różnica ta wynosi $0,05 \mathrm{~mm}$, to czas przejścia fali do wyżej położonego przetwornika jest o 35 ns dłuższy. W przypadku pomiaru naprężeń obwodowych w wieńcach kół kolejowych oznacza to stały, charakterystyczny dla danej głowicy błąd pomiaru równy ok. $20 \mathrm{MPa}$.

Poprawki dla każdej z głowic wyznaczane były początkowo na próbkach o znanej lub bliskiej zeru dwójłomności akustycznej. Obecnie wyznaczane są na izotropowych próbkach szklanych.
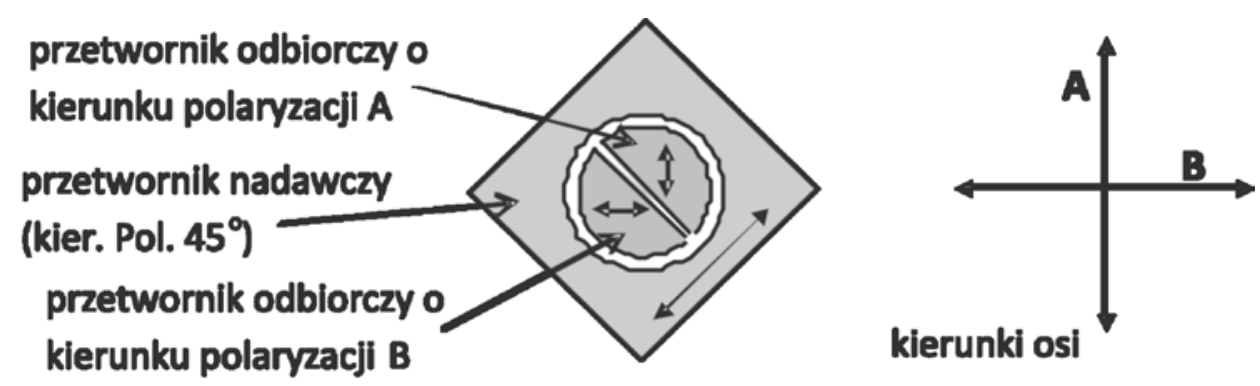

Rys. 3. Układ przetworników w nieobracanej, trójprzetwornikowaej głowicy do pomiaru dwójłomności akustycznej Fig. 3. The system of transmitters is not rotating of three- transducers head for measuring acoustic birefringence 
Głowice do badania kół zużytych metodą przepuszczania

Problemem w pomiarach dwójłomności w skrajnie zużytych kołach kolejowych, o małej grubości wieńca, są odbicia fal od jego bocznych powierzchni. Pokazano to schematycznie na rysunku 4.

Zmniejszenie rozbieżności wiązki, które mogłoby uchronić od odbić od bocznych powierzchni, można osiągnąć powiększając, wielkość przetwornika i podnosząc częstotliwość fal. W przypadku kół zużytych zwiększanie średnicy głowicy nie jest możliwe. Nie jest też możliwe, ze względu na wzrost tłumienia fal, wystarczająco wyraźne podniesienie częstotliwości fal poprzecznych. Jedyną metodą na pomiar dwójłomności $w$ takich kołach wydaje się skorzystanie $z$ techniki przepuszczania, z głowicą nadawczą połączona z jednym, a odbiorczą z drugim licem wieńca.

Wykonano głowicę nadawczą z przetwornikiem spolaryzowanym pod kątem $45^{\circ}$ przyłączoną do szerszej, wewnętrznej powierzchni wieńca i małą głowicę odbiorczą mieszczącą się na wąskim, zewnętrznym licu zużytego koła. Cechą głowicy odbiorczej powinna być niezależność wyniku pomiaru od wzajemnego, nie zawsze idealnie osiowego ustawienia obu głowic. W tym celu głowica odbiorcza została wyposażona w cztery małe, ułożone w szachownicę przetworniki. Układ przetworników w tej głowicy pokazano na rysunku 5. Zewnętrzna średnica tulei chroniącej przetworniki odbiorcze wynosiła jedynie $10 \mathrm{~mm}$.

Zakładano, że odbiór fal o wzajemnie prostopadłych kierunkach polaryzacji, przetwornikami ułożonymi pa-

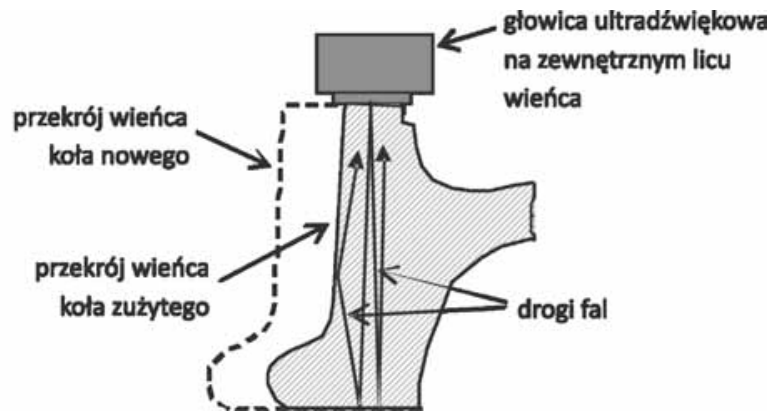

Rys. 4. Możliwe drogi fal podczas badania metodą echa koła skrajnie zużytego

Fig. 4. The possible ways of waves during the test method used echo extreme Wheel

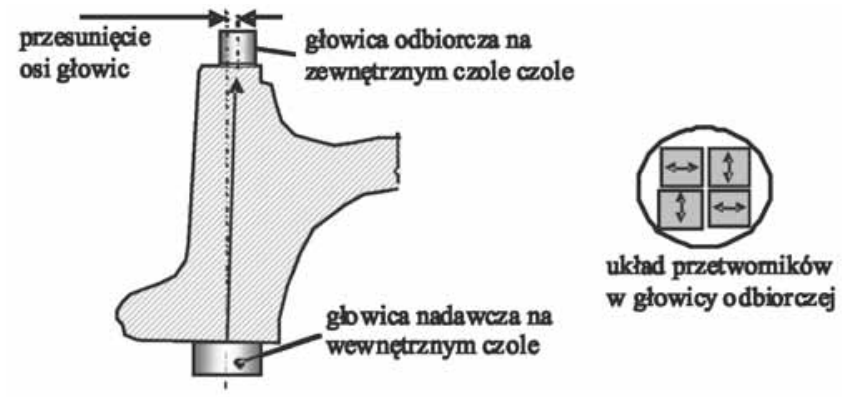

Rys. 5. Układ przetworników w miniaturowej głowicy odbiorczej do metody przepuszczania

Fig. 5. System in miniature sensors to pick-up transmission method

rami w szachownicę, uniezależni wynik pomiaru od nieznacznych odchyleń położenia głowicy odbiorczej od osi wiązki nadawanej przez głowicę nadawczą. Pomiary wykonane prototypowym zestawem wykazały, że ze względu na wahania sprzężenia akustycznego pod głowicą odbiorczą (sprzęganą często do nierównej, zdeformowanej i wąskiej powierzchni czoła zużytego koła) dają wyniki obarczone rozrzutem +/-50 MPa. Znaczny rozrzut wynikał również z faktu, że w technice przepuszczania droga fal $w$ materiale jest o połowę krótsza niż w technice echa. Stąd względna dokładność pomiaru czasu przejścia jest dwukrotnie gorsza.

\section{Głowice w układzie sandwicz}

Ciekawą perspektywę w poszukiwaniu układów mało wrażliwych na zmiany sprzężenia akustycznego stanowią przetworniki typu sandwicz. Jeśli przetworniki odbiorcze ułożone zostaną jeden nad drugim, to fala docierająca do każdego $z$ nich będzie przechodziła przez dokładnie tę samą warstwę sprzęgającą. Na rysunku 6 pokazano w przekroju możliwy "sandwiczowy” układ przetworników w głowicy trójprzetwornikowej. W otworze przetwornika nadawczego o kierunku polaryzacji $45^{\circ}$ ustawione są dwa okrągłe przetworniki odbiorcze. Dolny o polaryzacji A i górny o polaryzacji B. Ponieważ dolny przetwornik jest warstwą, przez którą fala musi przejść docierając do przetwornika górnego, jego grubość powinna wynosić $1 / 4$ długości fali. Oznacza to, że częstotliwość rezonansowa dolnego przetwornika powinna być dwukrotnie wyższa niż przetwornika górnego.

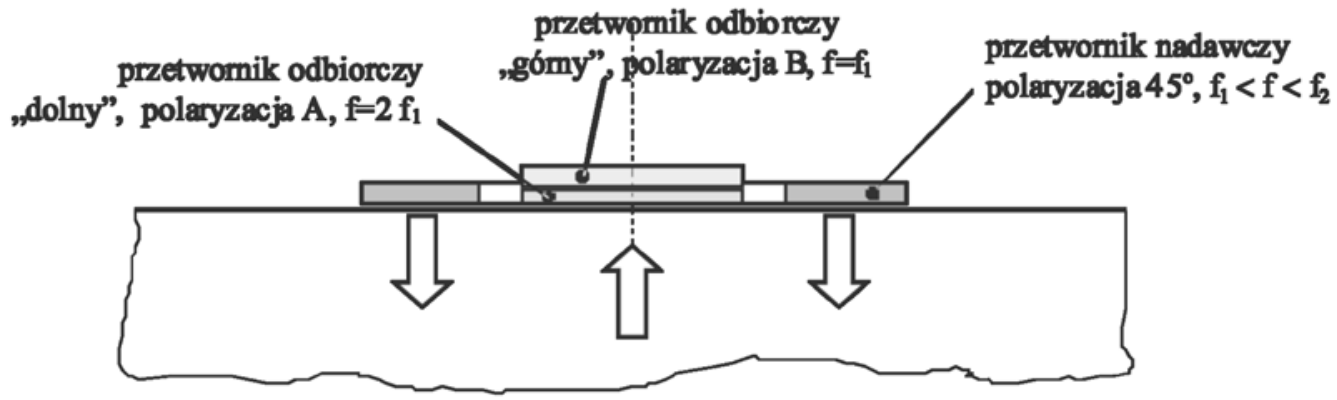

Rys. 6. Przekrój przetworników w „sandwiczowym” układzie głowicy trójprzetwronikowej

Fig. 6. Cross transmitters as sandwich type in the three-transducers head system. 
Badania prowadzone tak wykonanymi głowicami wykazały, że w pomiarach naprężeń w kołach kolejowych o wyraźnej teksturze (znaczna wartość $B_{T}$ we wzorze na dwójłomność) dostarczają one błędnych wartości. Jest to spowodowane tym, że całkowita dwójłomność materiału wieńca koła w znacznym stopniu wywołana jest teksturą stali. W odróżnieniu od dwójłomności na- prężeniowej, wartość dwójłomności teksturalnej jest silnie zależna od częstotliwości. Powodem błędów było więc zastosowanie różnych częstotliwości fal o wzajemnie prostopadłych kierunkach polaryzacji. Natomiast w pomiarach materiałów o zerowej lub bardzo niskiej teksturze, głowica typu „sandwicz” skutecznie redukuje wpływ sprzężenia akustycznego na wyniki.

\section{Literatura}

[1] Benson R., Realson V.G., Acoustoelasticity, Produkt Ingineering, Nr. 29, 1959.

[2] Rollins F.R., Study of Methods for Non-destructive Measurement of Residua Stress, WADD Technical Report, Part I, 1959, s. 56-69.

[3] Deputat J.: Własności i wykorzystanie zjawiska elastoakustycznego do pomiarów naprężeń własnych, Prace IPPT, Nr 28/1987.

[4] Jacquot T., Nogues M. and Hofmann U.: Residual stress analysis on heavy plates by ultrasonic testing Rev. Met. Paris, $N^{\circ} 10$ (October 2003), s.1023-1027

[5] Mackiewicz S., Szelążek J., Gutkiewicz P.,: Ultradźwiękowe badania degradacji pełzaniowej stali stosowanych w energetyce, Mat. XIX Seminarium Szkoleniowego „Badania Nieniszczące”, Zakopane, 12-15 marca 2013, s.39-60.
[6] Crecraft D.I.: Launching Ultrasonic Shear Waves in Solids a Normal Incydent by Pressure Coupling, J. Sound Vibr., Vol. 4, 1964, s.381-387.

[7] Crecraft D.I., The Measurement of Applied and Residua Stresses in Metals Rusing Ultrasonic Waves, J. Sound Vib., Vol 5 (I), 1967, s.173-192.

[8] Effect of Frequent Braking on Residual Stress Field in the Wheel Rim, Office of Research and Experiments UIC, B-169 Report 2, Utrecht 1989.

[9] Szelążek J.: Głowica ultradźwiękowa do pomiaru dwółłomności akustycznej, Patent Nr PL 167941, 22 listopada 1995.

[10]Schramm R.E., Szelążek J., Clark, Jr. A.V.: Dynamometerinduced Residual Stress in Railroad Wheels: Ultrasonic and Saw Cut Measurements, NISTIR 5043, Report No. 30, National Institute of Standards and Technology, Boulder, March 1995.

\section{\$ 4 METAL.PL}

\section{Ponad 2000 podwykonawców z całego świata}

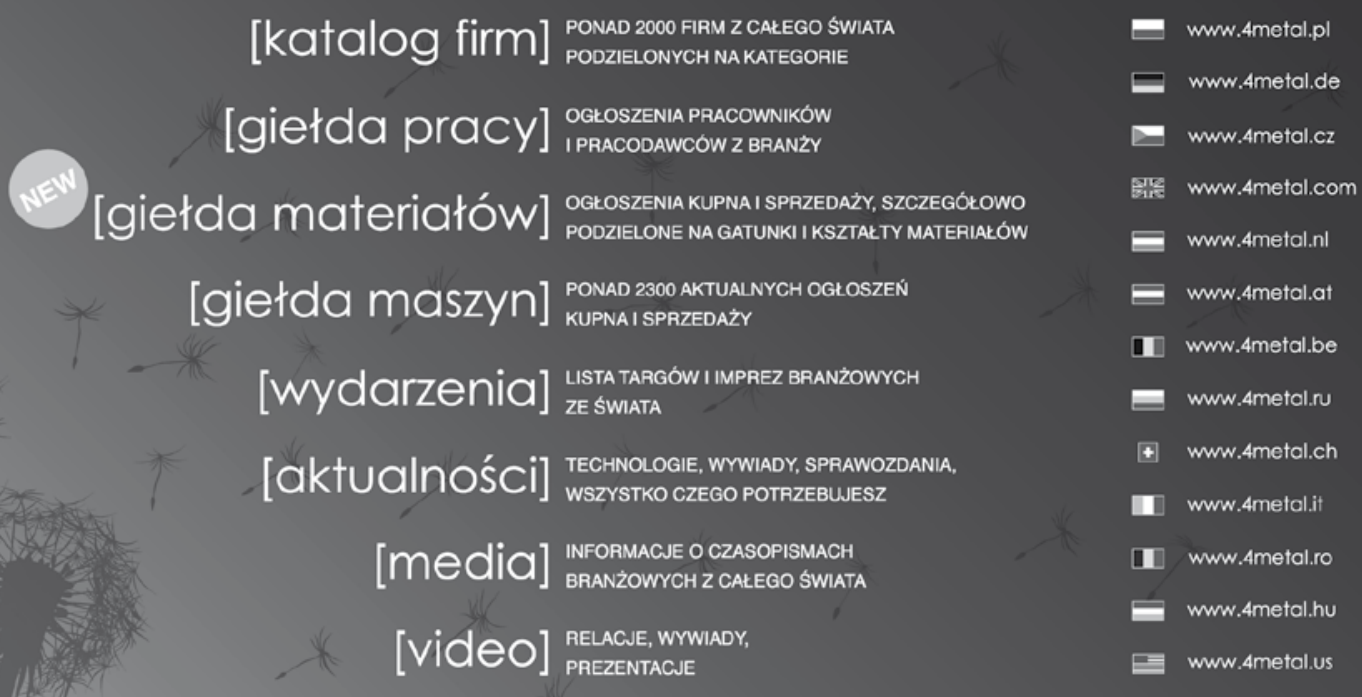

